\title{
Pre-service Teachers' Knowledge and Perceptions of the Impact of Mitigative Climate Actions and Their Willingness to Act
}

\author{
Sakari Tolppanen ${ }^{1}$ (D) Anna Claudelin ${ }^{2} \cdot$ Jingoo Kang $^{1}$ \\ Published online: 4 February 2020 \\ (C) The Author(s) 2020
}

\begin{abstract}
A 44-item questionnaire was created to examine pre-service teachers' knowledge and perceptions of the impact of mitigative climate change actions and how willing they are to undertake these actions. Responses $(N=224)$ were collected from pre-service teachers at the University of Eastern Finland. The findings show that pre-service teachers have a very low level of knowledge of the impact of different mitigative climate change actions. Furthermore, the students tend to overestimate the carbon footprint of low-impact actions and underestimate the carbon footprint of high-impact actions and they are unable to make a clear distinction between low- and high-impact actions, though the impact of the high-impact actions may be many times greater than those of low-impact actions. In general, pre-service teachers were willing to take low-impact actions, somewhat willing to take mid-impact actions, but reluctant to take the highest-impact actions. Knowledge of the impact of actions did not correlate with willingness to act, possibly due to low levels of knowledge. Some correlation between confidence in knowledge and willingness to act was found. This article discusses the importance of considering confidence in knowledge in future research examining the relationship between knowledge and action. The implications of the findings on teacher education and environmental education are also discussed.
\end{abstract}

Keywords Climate change education - Climate change mitigation - Climate change knowledge · Pro-environmental behavior - Willingness to act $\cdot$ Confidence in knowledge $\cdot$ Carbon footprint

Sakari Tolppanen

sakari.tolppanen@uef.fi

1 School of Applied Educational Science and Teacher Education, University of Eastern Finland, Yliopistokatu 7, 80130 Joensuu, Finland

2 School of Energy Systems, Lappeenranta-Lahti University of Technology LUT, Mukkulankatu 19, 15210 Lahti, Finland 


\section{Introduction}

Scientific consensus indicates that the climate is changing and that current changes are mostly driven by humans through increased greenhouse gas (GHG) emissions (IPCC, 2014a). As the consequences of climate change have been shown to pose serious risks to the environment and society, an immediate response to climate change is called for (IPCC, 2014b). Therefore, climate change mitigation is needed at both an individual and societal levels. While some may argue that the only way to achieve this is through international agreements that force the industry and citizens to change their consumption patterns, many have also argued for the importance of educating and empowering citizens to take action (e.g., Anderson, 2012, Schreiner et al., 2005).

In order to stay under $1.5{ }^{\circ} \mathrm{C}$ degrees of global warming, a goal set by the EU, the carbon footprint of individuals needs to be reduced significantly. For instance, it should be reduced to $2100 \mathrm{~kg}$ of $\mathrm{CO}_{2}$ eq by 2050 even to stay below a maximum temperature increase of $2{ }^{\circ} \mathrm{C}$ (Girod et al., 2014). In western countries, this means a three to ten-fold decrease, depending on the country (c.f. Ivanova et al. 2015). To reach such emission cuts, lifestyle changes should be focused especially on those actions that have a high impact on climate change. Although extensive research has been done on pro-environmental behavior and people's willingness to undertake certain actions, studies that consider the impact of different actions are scarce. For this reason, this study first examines pre-service teachers' understanding of the impact of different types of mitigative actions, and then examines how willing they are to take these actions.

\section{Literature Review}

\section{Impactful Climate Change Mitigation}

On a global level, 65-72\% of GHG emissions are related to household consumption (Hertwich and Peters 2009; Ivanova et al. 2015), the majority of which is caused by mobility, shelter, and food (Ivanova et al. 2015). Due to this high share of emissions caused by household activities, there are multiple ways individuals could reduce their GHG emissions. Different studies have calculated that the average consumer in a Western country could reduce their carbon footprint by at least $20-37 \%$ (Salo \& Nissinen 2017, Jones \& Kammen 2011) by making various changes to housing, transport, food, and purchased goods and services. Most importantly, these reductions are achievable with existing solutions and technologies.

While carbon footprints are globally at an average of $3.4 \mathrm{tCO}_{2} \mathrm{eq} / \mathrm{capita}$, in the EU the range is from Bulgaria's $5.4 \mathrm{tCO}_{2} \mathrm{eq} /$ cap to Luxembourg's $18.5 \mathrm{tCO}_{2} \mathrm{e} /$ cap. In the USA, the average carbon footprint is as high as $18.6 \mathrm{tCO}_{2}$ eq/cap (Ivanova et al. 2015). Finland's carbon footprint per capita (including embodied emissions) is among the highest in Europe at $11.5-13.6 \mathrm{tCO}_{2} \mathrm{eq} /$ a (Nissinen et al. 2017; Ivanova et al. 2015). On average, 39\% of this comes from housing, 19\% from transportation, $16 \%$ from food, and 26\% from goods and services (Salo \& Nissinen 2017).

To determine the individual actions that could have the biggest mitigative impact on climate change, Wynes and Nicholas (2017) categorized 148 different actions from 39 sources as high-, moderate-, and low-impact actions based on the GHG emissions of a particular action. In their study, all actions were framed to produce the highest possible reduction potential, and substitution effects and rebound effects were not taken into consideration due to lack of data. According to their study, high-impact actions, which can reduce GHG emissions by more than $0.8 \mathrm{tCO}_{2}$ eq/year, 
include having one fewer child, living car-free, avoiding air travel, and switching to a plant-based diet. In some regions, switching to green energy would also be classified as a high-impact action. Moderate impact actions (reduction potential of $0.2-0.8 \mathrm{tCO}_{2} \mathrm{eq} /$ year) include replacing a gasoline car with a hybrid car, washing clothes in cold water, recycling/reusing, and hand-drying clothes. The low-impact category includes upgrading light bulbs and conserving water.

These findings are mostly similar to calculations made in Finland. For instance, actions such as living car-free, avoiding air travel, and switching to a plant-based diet are also categorized as high-impact actions in Finland (Häkkinen and Kangas (2012). In fact, the only difference in categorizations seems to be in recycling, which Wynes and Nicholas (2017) have calculated as having a moderate impact of $210 \mathrm{kgCO}_{2} \mathrm{eq} / \mathrm{year}$, while in Finland it is calculated as having a low impact of only $18 \mathrm{kgCO}_{2}$ eq/year (see Appendix in Table 6), possibly due to differences in the factors connected to avoided GHG emissions and different baseline scenarios, i.e., amounts of waste and recyclable materials.

\section{Teachers' Knowledge of Climate Change and Climate Change Mitigation}

Given the scientific, political, and societal nature of climate change, many educators have emphasized that it is one of the most important socio-scientific issues that teachers should address with students (e.g., Dawson, 2015, Schreiner et al., 2005). Unfortunately, numerous studies have shown that teachers' and pre-service teachers' knowledge of the causes and consequences of climate change is unacceptably low. For example, a study conducted in Finland shows that the factual knowledge and conceptual understanding of the greenhouse effect by pre-service teachers is incomplete and even incorrect (Ratinen, 2013). Similar findings are reported in other countries such as Australia (Boon, 2010), Canada (Puk \& Stibbards, 2012), and the USA (Lambert \& Bleicher, 2013).

Due to the lack of knowledge of climate change issues, it is fair to assume that knowledge of climate change mitigation is also low. However, studies examining knowledge of the impact of different mitigative actions are scarce if not non-existent, as most studies typically only examine participants' perceptions of mitigative actions. Nonetheless, studies on perceptions help give a general understanding of pre-service teachers' conceptions and misconceptions of mitigative issues when compared with literature on the impact of these actions. For instance, a Greek study showed that the majority of teachers believed that climate change can be mitigated by recycling paper, while not believing that nuclear power is a good option to do so (Ikonomidis, et al., 2012). However, research shows that the mitigative impact of recycling is relatively low (Wynes and Nicholas, 2017), whereas nuclear power can be a significant way to reduce carbon emissions (Gibson et al., 2017). Similarly, a study conducted in Oman showed that pre-service teachers believe that recycling and turning off devices are more useful than reducing meat consumption and improving home insulation (Ambusaidi et al., 2012), when in fact the opposite is true (Wynes and Nicholas, 2017; Lim et al., 2016). These studies indicate that pre-service teachers' knowledge of mitigative actions is low and that education on climate change mitigation is called for. Similar findings have been noted among the general public in energy-related issues, which are closely related to climate change. For instance, a study showed that participants underestimate the saving capacity of different proenvironmental energy-related behaviors by an average factor of 2.8 , and the importance of high-energy activities was particularly underestimated (Attari et al., 2010).

Educators have pointed out that climate change education should help improve the ability of students to take action, also called action competence (Jensen, 2002; Jensen \& Schnack, 
1997). In order to do so, teachers need to understand the impact of different mitigative actions, as students tend to ask questions related to the usefulness of different types of actions (Tolppanen \& Aksela, 2018). Teachers therefore need to be able to distinguish which mitigative actions have a greater impact. For instance, reducing the number of annual long-distance flights by one can have a greater positive impact on climate change mitigation than recycling all household garbage for many years (see, e.g., Wynes and Nicholas, 2017). Furthermore, correct knowledge of mitigative actions is important, so that individuals do not think that they are living an environmentally friendly life when their calculated carbon footprint actually indicates the opposite. This current study examines pre-service teachers' perceptions and knowledge of mitigative actions and their willingness to take mitigative action.

\section{Willingness to Take Action}

Although individuals are concerned about climate change (e.g., Ilmastobarometri, 2019) and carbon footprint calculators have been available for decades, carbon footprints have not significantly decreased in recent years. One reason is that individuals, including teachers, tend only to take low-impact mitigative actions (e.g., Hermans, 2016; Ambusaidi et al., 2012).

Researchers have made many potential suggestions as to why individuals are not taking more mitigative actions. For instance, a study conducted in the UK shows that barriers to adopting climate mitigative action are caused by a lack of knowledge of consequences and potential solutions (Lorenzoni et al., 2007). However, the relationship between knowledge and action is complex. Although research has shown that knowledge and pro-environmental action are strongly interrelated (e.g., Zsóka et al., 2013), there is also abundant evidence showing that an increase in knowledge does not necessarily increase pro-environmental action (Kollmuss \& Agyeman, 2002). This dissociation between knowledge and actions has been discussed for decades and is often referred to as the "knowledge-behavior gap" (see Kollmuss \& Agyeman, 2002) or a "commitment gap" (Emanuel, \& Adams, 2011).

A number of factors may account for the knowledge-behavior gap. Firstly, behavior is influenced by many other variables besides knowledge. These can include attitudes towards the environment, social acceptance of a behavior, values, and situational factors such as ease of taking an action (Steg and Vlek, 2009). Therefore, although knowledge of an environmental issue may be necessary in order to take pro-environmental action, alone it may not lead to taking action (e.g. Balmford, et al., 2017). Second, the knowledge-behavior gap may be caused by educational objectives that are too narrow (Boyes et al., 2009). Jensen (2002) has argued that "environmental knowledge" should not only refer to knowledge of environmental "effects" but also examine the "root causes," "strategies for change," and "alternatives and visions". For instance, in a recent model for holistic climate change education, researchers suggest that climate change education should include knowledge of issues such as adaptation, political decision-making, human behavior, and emotional aspects (Tolppanen et al. 2017; Cantell et al. 2019). The assumption is that when "knowledge" also includes an understanding on impactful behavior and possible hindrances to taking action, the gap between knowledge and behavior narrows. In other words, knowledge is only one factor among many for the development of climate change understanding and the ability to take action (Tolppanen, et al., 2017; Cantell, et al., 2019). Third, the knowledge-behavior gap is also partially due to the fact that some studies examine a relationship between general environmental knowledge and overall pro-environmental behavior, rather than specific knowledge and behaviors (Kollmuss \& Agyeman, 2002). This is problematic, especially in a climate change context, where different behaviors can have significant differences in 
their mitigative impact, as discussed above. Finally, individuals may resort to "single-action bias" (see Weber, 2010), meaning that they try to justify their behavior by over-concentrating on single mitigative actions and over-emphasizing the impacts of these actions. This may lead individuals to underestimate the impact of high-impact actions and overestimate the impact of low-impact actions.

For climate change mitigation to be possible, education should aim to narrow the knowledge-behavior gap. Teachers in particular play an important role in this, as they may work as "socializers" or influencers for students and may affect how their students perceive and implement pro-environmental behavior (Chawla, 2009). However, as suggested by the social cognitive theory (e.g., Bandura, 2011), for teachers to be influencers of climate change mitigation, they first need to understand climate change mitigation actions and be willing to take mitigative actions themselves. We therefore first need to broaden our view of what is meant by climate change knowledge to also include knowledge of mitigative actions. Research is then needed to examine how pre-service teachers adopt and learn this knowledge and, even more importantly, how they are able and willing to take individual action and teach climate change mitigation to their students. Furthermore, for education to be able to address climate change mitigation in a meaningful way, students' pre-knowledge and pre-conceptions must be understood. Only then will education be able to be implemented in a way that supports conceptual change (Posner et al., 1982) in impactful mitigative actions.

\section{The Current Study}

As studies measuring pre-service teachers' knowledge of mitigative actions are scarce and previous studies have not considered the importance of confidence in knowledge, the current study examines pre-service teachers' knowledge and confidence in knowledge of mitigative actions and compares these to their willingness to take action. The aim of the study was to answer the following research questions:

1. How knowledgeable are pre-service teachers about the impact of mitigative climate change actions and how confident are they in their knowledge?

2. How does knowledge and confidence in knowledge correlate with pre-service teachers' willingness to take mitigative climate change action?

\section{Method}

\section{Sample and Data Collection}

Data was collected from 255 primary school pre-service teachers, who participated in a course on Education for Sustainability, held by the University of Eastern Finland. Among them, 224 participants agreed to offer their data for this research. The participants were at various stages of their pre-service teacher training. The data was collected through a closed form questionnaire, containing a total of 44 items. The questionnaire was filled out prior to lessons on climate change-related issues to measure participants' pre-knowledge. By measuring preknowledge, the findings give an indication of the level of knowledge of teachers who have not received formal education on climate change-related issues, as most teachers have not. 


\section{Measures}

The questionnaire created for this study contained two sections. The first section contained 19 items measuring knowledge and perceptions of climate change mitigation (CCM). The questions included 3-4 items from each of the following six categories: Car use, Diet, Travel, Consumption and Recycling, Lifestyle and Housing. The items for the questionnaire were chosen so that they measured a wide range of mitigative actions. In this section, participants were asked to evaluate the size of the carbon emissions of each of the actions, using an 11-point scale, where answers were given from a range of $0-100 \mathrm{kgCO}_{2}$ eq to $1000+\mathrm{kgCO}_{2}$ eq (the scales were $0-100,101-200,201-$ 300 , etc.). Furthermore, after the questions in each of the six categories, participants used a fourpoint Likert scale to indicate how confident they were about their answers. As it was mandatory to answer all the questions, the confidence scale was used as an indicator of whether the participants thought they knew the answer, or whether they may have been guessing their answers.

The impactt of each of the 19 mitigative actions was calculated using existing research data (see Appendix in Table 6) allowing scrutiny of the correctness of the participants' answers, so the aim of the CCM questionnaire was two-fold. First, it gave data on the perception that pre-service teachers have of the impact of different mitigative actions. Second, by comparing participants' perceptions of the actual impact of the mitigative actions, it gave insight into the level of knowledge that pre-service teachers have of the mitigative actions. To examine the level of knowledge of participants, the goal was not to see whether the participants could point out the exact correct value for the mitigative action. Rather, the goal was to understand if the participant had a general understanding of the impact of the mitigative actions. For this reason, when examining the correctness of the answers, a minimum margin of error of $\pm 100 \mathrm{kgCO}_{2}$ eq was allowed. In other words, if the correct answer was in the range of 301-400 $\mathrm{kgCO}_{2} \mathrm{eq}$, answers would be considered correct if they were in the range of 201-500 $\mathrm{kgCO}_{2}$ eq. This approach also took into consideration the possible margin of errors in calculating the carbon emissions of a mitigative action. The format of the questions was adopted from Boyes et al. (2009), but as the carbon emissions of the actions needed to be calculated, some questions were modified, some were added, and some omitted.

The second section of the questionnaire measured Willingness to Take Action (W-ACT). This section of the questionnaire also contained 19 items, which were partially adopted from Boyes et al. (2009). The items were created to form pairs with the questions in the previous section (CCM). For instance, if in the first section the participant needed to estimate how much an individual's annual GHG emissions would decrease due to a certain action, in the second section they needed to answer to what extent they were willing to participate in that particular action for environmental reasons. Answers to this section were given on a 5-point Likert scale from very unwilling to very willing.

The questionnaire was scrutinized by a group of researchers consisting of three experts in education and two experts in climate change. After slight modification of a few of the questions, the questionnaire was then trialed with 26 university students. The wording of questions was then modified based on feedback.

As shown in Table 1, the questions in the CCM and W-ACT questionnaire were grouped into seven categories based on the topic areas and the impact of the mitigative actions.

\section{Analysis}

We first conducted descriptive analyses for four core variables - perception, willingness, content knowledge, and confidence in one's own knowledge. Regarding perception and willingness, we used their own scale ranges ( 11 for $\mathrm{kgCO}_{2} \mathrm{eq}$ and 5 for willingness to act) since we mostly focused 
on the correlation of the four constructs for further analyses. In order to make the knowledge-related variables, we created dummy variables for each question ( 1 for the correct answer and 0 for the wrong answer) and calculated the average scores of each topic. Regarding confidence in the knowledge of CCM, the participants were asked to indicate how confident they were about their answers on each topic using a four-point Likert scale (very unconfident, somewhat unconfident,

Table 1 Calculated carbon footprint of actions, wording, and categories used in this study

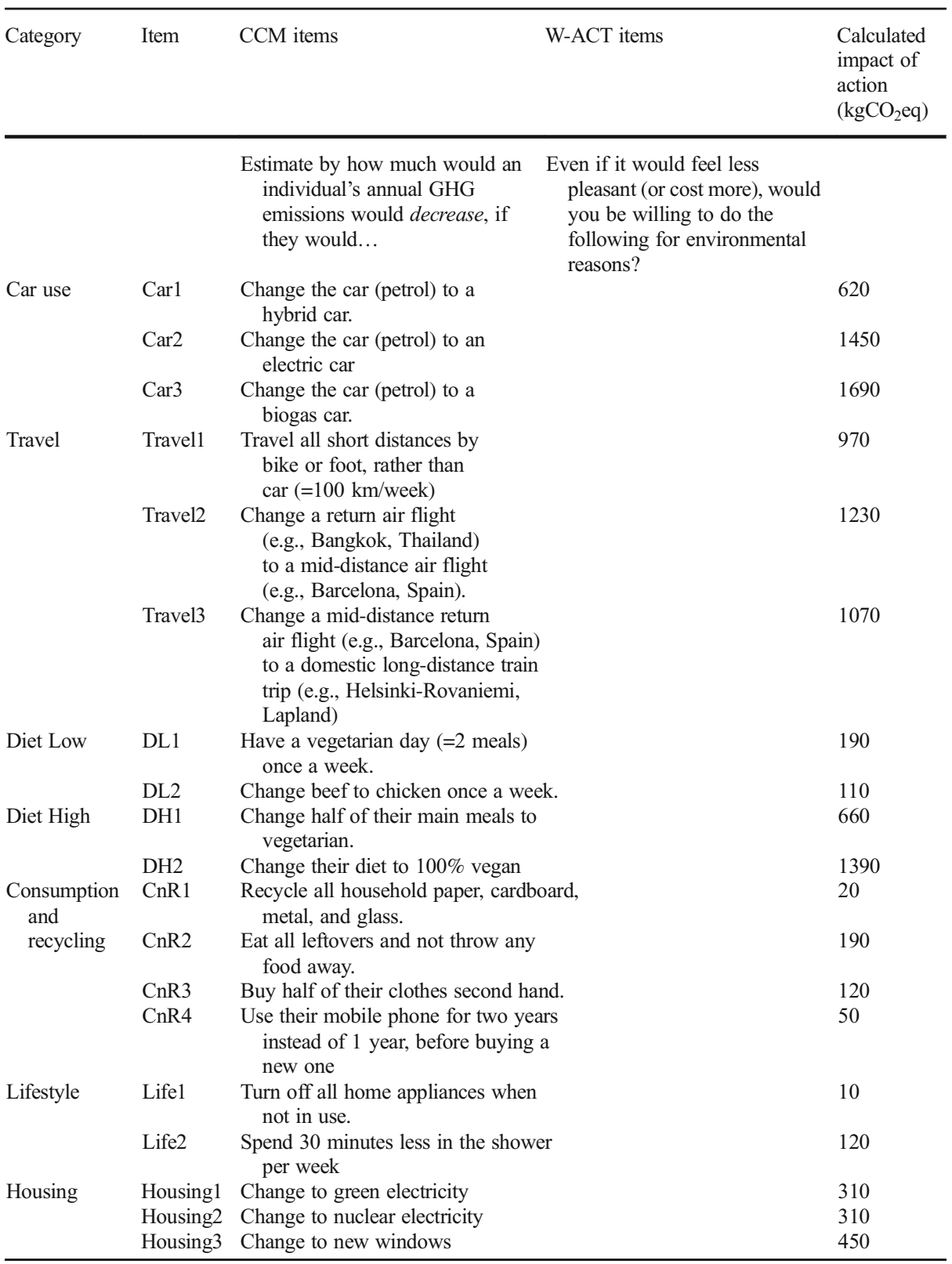


somewhat confident, and very confident). As a very small proportion of participants were somewhat confident or very confident in their answers, we concluded that a binary yes/no scale would give enough information about the participants' confidence, so we combined the first two scales into "unconfident" and the last two scales into "confident," then calculated the averages for the confidence-related variables of each topic. With the created compound variables, correlation analyses were conducted to explore the relationships between the four core constructs in the seven topics. First, we investigated the association between willingness and perception, and willingness and knowledge, to find if perception and knowledge might affect willingness on mitigative actions. Second, we investigated the relationships between confidence and knowledge, and confidence and willingness, to check how the confidence of the knowledge might correlate with willingness to take action. In our correlation analyses, we only focused on the relationships under the same topic. That is, our results reported the correlation of knowledge of Diet Low with the perception of Diet Low only, not with the perception of Energy or Lifestyle, for instance.

\section{Results}

\section{Descriptive Statistics}

Pre-service teachers' level of knowledge of mitigative issues was the highest in issues related to Housing. In this group, 39-50\% of participants correctly stated the impact of these actions. Participants were also relatively knowledgeable about the impact of Diet, especially on the impact of switching to a vegetarian or vegan diet (40-42\% correct). Level of knowledge was lowest on issues regarding questions in the Consumption and Recycling and Lifestyle categories. In these categories only $11-22 \%$ of participants were able to correctly answer the questions. In questions related to Travel, the discrepancy within the group was largest, ranging from 23 to $39 \%$ of participants answering the questions correctly (see Table 2).

As shown in Table 2, most pre-service teachers have incorrect knowledge of the impact of particular mitigative actions. Furthermore, the pre-service teachers perceived the high-impact actions as having a lower impact than they actually do, and the low-impact actions to have a higher impact than they actually do. In most of the questions measuring high-impact actions, over $30 \%$ of the participants perceived these actions as having an impact of less than $500 \mathrm{kgCO}_{2}$ eq. For instance, $39.7 \%$ of students believed that traveling all short distances by bike or on foot would decrease their carbon footprint by under $500 \mathrm{kgCO}_{2} \mathrm{eq}$, where in reality the reduction is $970 \mathrm{kgCO}_{2}$ eq. In other words, a big proportion of pre-service teachers perceived the impact of the action to be at least twice as small as it actually is.

A similar but greater misconception is seen regarding low-impact actions. In all but dietrelated questions, 30-40\% of participants believed that low-impact actions had an impact of above $500 \mathrm{kgCO}_{2}$ eq. For instance, over $42 \%$ of participants believed that buying half their clothes second-hand would have a medium-high or high impact, whereas in fact the impact of the action is only $120 \mathrm{kgCO}_{2} \mathrm{eq}$, or 4-7 times smaller than the pre-service teachers perceived it to be. Disturbingly, more pre-service teachers perceived the action to have a high impact rather than a low impact $(12.1 \%$ and $11.6 \%$ respectively).

The findings show that pre-service teachers show high willingness to undertake the lowestimpact actions (see Fig. 1). Willingness to take actions related to Lifestyle and Consumption and Recycling was especially common. In these categories, $75 \%$ of participants were quite willing or very willing to take action, with the exception of buying half of their clothes second- 
Table 2 Pre-service teachers' perceptions of mitigative climate change actions. Correct answers marked in bold

\begin{tabular}{|c|c|c|c|c|c|}
\hline & & $\begin{array}{l}\text { Low } 0-200 \\
\mathrm{kgCO}_{2} \mathrm{eq}\end{array}$ & $\begin{array}{l}\text { Low- } \\
\text { medium } \\
201-500 \\
\mathrm{kgCO}_{2} \mathrm{eq}\end{array}$ & $\begin{array}{l}\text { Medium- } \\
\text { high } \\
501-800 \\
\mathrm{kgCO}_{2} \mathrm{eq}\end{array}$ & $\begin{array}{l}\text { High } \\
800+ \\
\mathrm{kgCO}_{2} \mathrm{eq}\end{array}$ \\
\hline \multirow[t]{3}{*}{ Car use } & Change to a hybrid car. & $8.5 \%$ & $51.8 \%$ & $28.1 \%$ & $11.6 \%$ \\
\hline & Change to an electric car & $4.5 \%$ & $30.9 \%$ & $32.7 \%$ & $31.8 \%$ \\
\hline & Change to a biogas car. & $4.5 \%$ & $30.8 \%$ & $35.7 \%$ & $29 \%$ \\
\hline \multirow[t]{3}{*}{ Travel } & $\begin{array}{l}\text { Travel all short distances by bike or } \\
\text { on foot }\end{array}$ & $9.8 \%$ & $29.9 \%$ & $35.7 \%$ & $24.6 \%$ \\
\hline & $\begin{array}{l}\text { Change a long-distance flight to a } \\
\text { mid-distance one }\end{array}$ & $7.6 \%$ & $37.1 \%$ & $32.6 \%$ & $22.8 \%$ \\
\hline & $\begin{array}{l}\text { Change a mid-distance flight to a } \\
\text { domestic train journey }\end{array}$ & $8.1 \%$ & $29.1 \%$ & $24.2 \%$ & $38.6 \%$ \\
\hline \multirow[t]{2}{*}{ Diet High } & $\begin{array}{l}\text { Change half of main meals to } \\
\text { vegetarian. }\end{array}$ & $7.6 \%$ & $38.1 \%$ & $40.8 \%$ & $13.5 \%$ \\
\hline & Change diet to $100 \%$ vegan & $5 \%$ & $22.5 \%$ & $30.2 \%$ & $42.3 \%$ \\
\hline \multirow[t]{2}{*}{ Diet Low } & Have a vegetarian day once a week. & $25 \%$ & $59.8 \%$ & $14.3 \%$ & $0.9 \%$ \\
\hline & Change beef to chicken once a week. & $36.5 \%$ & $46.4 \%$ & $15.3 \%$ & $1.8 \%$ \\
\hline \multirow{4}{*}{$\begin{array}{l}\text { Consumption and } \\
\text { recycling }\end{array}$} & Recycle all household waste & $14.8 \%$ & $46.2 \%$ & $25.6 \%$ & $13.5 \%$ \\
\hline & $\begin{array}{l}\text { Eat all leftovers and not throw any } \\
\text { food away. }\end{array}$ & $13.8 \%$ & $42.4 \%$ & $33 \%$ & $10.7 \%$ \\
\hline & Buy half of clothes second-hand. & $11.6 \%$ & $46 \%$ & $30.4 \%$ & $12.1 \%$ \\
\hline & $\begin{array}{l}\text { Use mobile phone for two years } \\
\text { instead of one. }\end{array}$ & $20.5 \%$ & $42.9 \%$ & $27.2 \%$ & $9.4 \%$ \\
\hline \multirow[t]{2}{*}{ Lifestyle } & $\begin{array}{l}\text { Turn off all home appliances when } \\
\text { not in use. }\end{array}$ & $21.9 \%$ & $43.8 \%$ & $24.6 \%$ & $9.8 \%$ \\
\hline & $\begin{array}{l}\text { Spend } 30 \text { minutes less in the shower } \\
\text { per week }\end{array}$ & $18.8 \%$ & $48.2 \%$ & $25.9 \%$ & $7.1 \%$ \\
\hline \multirow[t]{3}{*}{ Housing } & Change to green electricity & $14.3 \%$ & $49.8 \%$ & $28.7 \%$ & $7.2 \%$ \\
\hline & Change to nuclear electricity & $36.5 \%$ & $39.2 \%$ & $18 \%$ & $6.3 \%$ \\
\hline & Change to new windows & $21.5 \%$ & $49.8 \%$ & $24.7 \%$ & $4 \%$ \\
\hline
\end{tabular}

hand, in which case $48 \%$ of participants were willing to do so. Most (over 90\%) of the preservice teachers were also quite willing or very willing to take action in minor diet-related issues (Diet1) but showed less enthusiasm to take action in diet-related issues with a higher impact (Diet2). Changing to a vegan diet in particular was something that only $16 \%$ of the participants were willing to do. The majority of pre-service teachers were willing to take action in housing-related issues, especially changing to green energy (68\%) and changing to better insulated windows $(61 \%)$, but less than $50 \%$ of them were willing to take high-impact actions (over $800 \mathrm{kgCO}_{2} \mathrm{eq}$ ), with the exceptions of walking or biking all short distances $(75 \%)$ and changing a long-distance flight (e.g., Bangkok) to a mid-distance flight (e.g., Barcelona) (60\%). Participants were least willing to change to a vegan diet (16\%) and change their holiday plans from an international mid-distance flight (e.g., Barcelona) to a domestic train journey (e.g., to Lapland) (27\%).

To simplify the grouping of the data, the impact of the mitigative actions was divided into two categories: high-impact (over $500 \mathrm{kgCO}_{2}$ eq) and low-impact (below $500 \mathrm{kgCO}_{2}$ eq). For instance, while both Diet Low and Diet High dealt with change of diet for environmental reasons, they were put into two different categories as questions in Diet Low consisted of the low-impact actions while questions in Diet High consisted of the high-impact actions. The grouped data in Table 3 clearly shows that pre-service teachers are more willing to take lowimpact actions than to take high-impact actions, even though they did not perceive these actions 


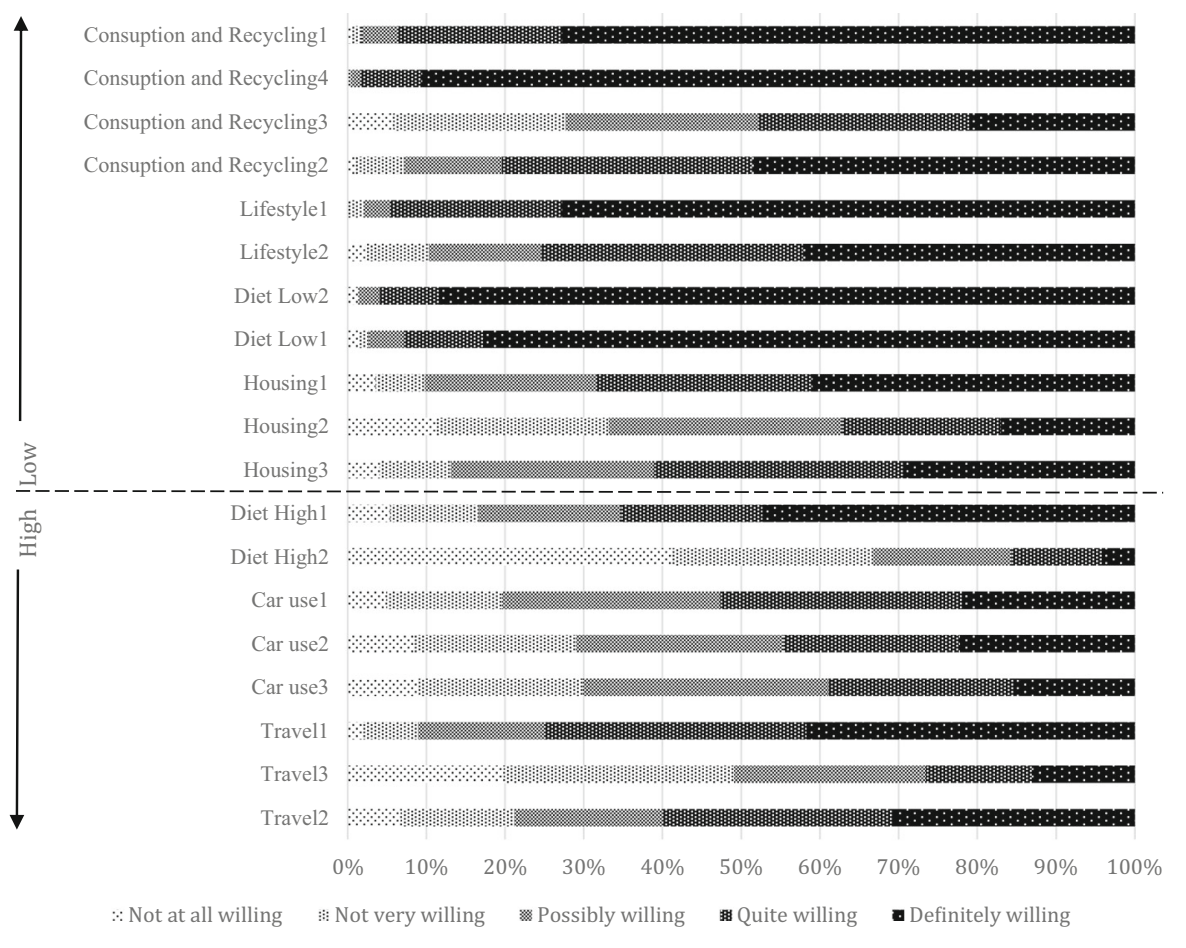

Fig. 1 Pre-service teachers' willingness to take mitigative climate change actions

to be the most effective. The results show that, in general, the participants perceived highimpact mitigative actions (Diet2, Travel, and Driving) to have a greater environmental impact than low-impact actions (Consumption and Recycling, Lifestyle, Living, and Diet1), but the data also shows that the teachers often perceived the difference between high-impact and lowimpact actions as marginal, although in fact the differences may be very large. For instance, the

Table 3 Pre-service teachers' confidence in the knowledge and descriptive analysis of their perceptions of mitigative actions and their willingness to act

\begin{tabular}{|c|c|c|c|c|}
\hline \multirow[t]{2}{*}{ Topic (impact) } & \multicolumn{4}{|c|}{$\begin{array}{l}\text { Core construct } \\
\text { (range) }\end{array}$} \\
\hline & $\begin{array}{l}\text { Perception } \\
(1-11) \\
\text { Mean (S.D) }\end{array}$ & $\begin{array}{l}\text { Willingness } \\
(1-5)\end{array}$ & $\begin{array}{l}\text { Knowledge } \\
\text { Percentage }\end{array}$ & Confidence in knowledge \\
\hline $\begin{array}{r}\text { Diet High (high) } \\
\text { Travel (high) } \\
\text { Car use (high) } \\
\text { Consumption and Recycling (low) } \\
\text { Lifestyle (low) } \\
\text { Housing (low) } \\
\text { Diet Low (low) }\end{array}$ & $\begin{array}{l}6.60(2.44) \\
6.50(2.33) \\
6.30(2.24) \\
5.13(2.18) \\
4.67(2.32) \\
4.37(1.78) \\
3.60(1.71)\end{array}$ & $\begin{array}{l}3.00(1.11) \\
3.47(0.95) \\
3.32(1.09) \\
4.27(0.52) \\
4.35(0.69) \\
3.59(0.85) \\
4.76(0.57)\end{array}$ & $\begin{array}{l}42 \% \\
29 \% \\
30 \% \\
15 \% \\
20 \% \\
46 \% \\
31 \%\end{array}$ & $\begin{array}{l}8 \% \\
9 \% \\
4 \% \\
8 \% \\
12 \% \\
6 \% \\
8 \%\end{array}$ \\
\hline
\end{tabular}


mean values for the impact of Car use (6.3) and Consumption and Recycling (5.13) are relatively close to each other, although in reality the impact of the actions related to Car use is many times greater than those related to Consumption and Recycling (see Table 1 for comparison). Intriguingly, less than $12 \%$ of the pre-service teachers were confident or somewhat confident about their answers.

\section{Correlation}

To determine whether there is a relationship between willingness to act and participants' perceptions of impact or knowledge of impact, we examined the correlation in the seven categories.

As shown in the upper part of Table 4, there were no significant correlations between the constructs of willingness and perception, except in Lifestyle (.137), which indicated a small effect. In addition, significant correlations were not found between willingness to act and knowledge of impact (see the lower part of Table 4). That is, the students' willingness to act is not affected by their perceptions or knowledge of the impact of the actions, but by some other factors. However, since the participants' confidence in their own knowledge was very low, it is hard to conclude that knowledge may not impact willingness to act, so we further explored the relationships of knowledge and willingness to act by examining the confidence in knowledge that the teachers had.

Confidence in knowledge positively correlated with knowledge of three of the high-impact mitigative actions (Car use (.215), Diet2 (.137) and Travel (.236)), although the effect sizes were small (see the upper part of Table 5). A positive correlation was also found between confidence of knowledge and willingness to act on Travel-related (.134) and Housing-related (.175) issues (see the lower part of Table 5). We can therefore assume that, for instance, when students get more

Table 4 Correlation between willingness, perception, and knowledge

\begin{tabular}{|c|c|c|c|c|c|c|c|}
\hline Willingness & Diet High & Car use & Travel & $\begin{array}{l}\text { Consumption } \\
\text { \& Recycling }\end{array}$ & Lifestyle & Housing & $\begin{array}{l}\text { Diet } \\
\text { Low }\end{array}$ \\
\hline \multicolumn{8}{|l|}{ Perception } \\
\hline Diet High & .044 & .065 & -.049 & -.039 & .036 & .041 & $.154^{*}$ \\
\hline Driving & -.035 & -.035 & -.116 & $-.147^{*}$ & .093 & -.052 & -.002 \\
\hline Travel & -.012 & .043 & .035 & -.059 & .035 & -.012 & .084 \\
\hline $\begin{array}{r}\text { Consumption \& } \\
\text { Recycling }\end{array}$ & -.030 & .096 & -.003 & -.040 & .113 & .035 & .110 \\
\hline Lifestyle & -.016 & .097 & -.019 & -.061 & $.137^{*}$ & .035 & .087 \\
\hline Housing & .059 & .103 & .066 & .114 & .095 & .106 & .058 \\
\hline Diet Low & .054 & .116 & .020 & .005 & .029 & .104 & .102 \\
\hline \multicolumn{8}{|l|}{ Knowledge } \\
\hline Diet High & .040 & .022 & .053 & -.038 & .034 & .050 & .077 \\
\hline Driving & $-.140^{*}$ & -.061 & -.123 & $-.208^{* *}$ & .024 & -.041 & -.071 \\
\hline Travel & -.032 & .025 & .039 & -.081 & -.001 & .038 & .029 \\
\hline $\begin{array}{r}\text { Consumption \& } \\
\text { Recycling }\end{array}$ & .032 & -.089 & .003 & .061 & -.085 & -.016 & $-.132^{*}$ \\
\hline Lifestyle & .064 & -.006 & .028 & .093 & .004 & .028 & $-.134^{*}$ \\
\hline Housing & .013 & -.084 & -.064 & -.096 & -.038 & -.036 & -.004 \\
\hline Diet Low & .072 & .015 & -.002 & .047 & .012 & -.023 & -.063 \\
\hline
\end{tabular}


knowledge of the impact of mitigative actions related to Travel, their confidence in their knowledge of Travel will increase, and their increasing confidence in their knowledge of Travel will affect their willingness to engage positively with the Travel-related mitigative actions. Therefore, although no relationships were found between mere knowledge and willingness, achieving knowledge with confidence may be an important factor in making students participate in mitigative actions.

\section{Discussion}

Previous studies have found that pre-service teachers' understanding of climate change issues is unacceptably low (e.g., Ratinen, 2013; Boon, 2010; Puk \& Stibbards 2012; Lambert \& Bleicher, 2013). The findings of this study show that this is also the case regarding knowledge of mitigative actions. More specifically, this study shows that, at best, Finnish pre-service teachers have a vague understanding of the mitigative impact of different actions but in general their level of knowledge and especially their confidence in their knowledge of mitigative actions are low. The low level of knowledge shows that the majority of pre-service teachers had false perceptions of the impact of mitigative actions. Participants especially underestimated the impact of high-impact actions and overestimated the impact of low-impact actions, a trend that was also noted in the context of energy by Attari et al. (2010). Significantly, this study gives insight into how big of a problem this issue with false perceptions really is. For instance, the data shows that pre-service teachers consider consumption- and recycling-related activities to have almost an equal impact on climate change to travel, although the items in the travel category are actually 5-10 times more effective mitigative actions than those in consumption and recycling. In essence, pre-service teachers seem to consider all mitigative actions to have a moderate impact and are unable clearly to distinguish between lowand high-impact actions.

Table 5 Correlation between certainty, knowledge, and willingness

\begin{tabular}{|c|c|c|c|c|c|c|}
\hline Certainty & Car use & Diet & Travel & $\begin{array}{l}\text { Consumption } \\
\text { \& Recycling }\end{array}$ & Lifestyle & Housing \\
\hline \multicolumn{7}{|l|}{ Knowledge } \\
\hline Car use & $.215^{* *}$ & .131 & .108 & $.139^{*}$ & $.183^{* *}$ & .066 \\
\hline Diet High & .114 & $.137^{*}$ & .085 & .087 & .050 & .027 \\
\hline Diet Low & -.081 & -.044 & -.094 & $-.143^{*}$ & -.066 & -.083 \\
\hline Travel & .116 & .097 & $.236^{* *}$ & .129 & $.157^{*}$ & $.137^{*}$ \\
\hline $\begin{array}{r}\text { Consumption \& } \\
\text { Recycling }\end{array}$ & .023 & -.002 & -.013 & .000 & .048 & -.013 \\
\hline Lifestyle & .061 & .044 & .004 & .020 & .042 & .034 \\
\hline Housing & .042 & .087 & -.009 & .011 & -.004 & .066 \\
\hline \multicolumn{7}{|l|}{ Willingness } \\
\hline Driving & .042 & .073 & .065 & .043 & .013 & .086 \\
\hline Diet High & -.080 & .115 & -.008 & .003 & -.029 & -.025 \\
\hline Diet Low & -.120 & .057 & -.052 & .006 & .003 & -.039 \\
\hline Travel & .053 & .111 & $.134^{*}$ & $.179^{* *}$ & .104 & .085 \\
\hline $\begin{array}{r}\text { Consumption \& } \\
\text { Recycling }\end{array}$ & -.043 & .042 & -.036 & -.063 & -.095 & -.099 \\
\hline Lifestyle & .092 & $.141^{*}$ & .103 & .101 & .028 & .071 \\
\hline Housing & $.169^{*}$ & $.151^{*}$ & $.150^{*}$ & .107 & $.137^{*}$ & $.175^{* *}$ \\
\hline
\end{tabular}




\section{Increasing Knowledge to Support Action Competence}

The findings suggest that, in order for pre-service teachers to teach action competence (Jensen 2002; Jensen, \& Schnack, 1997), empower their students to take action (e.g., Anderson, 2012; Schreiner, et al. 2005), and address students' questions on climate change mitigation (Tolppanen \& Aksela, 2018), they need more specific knowledge of the impact of different mitigative actions. Furthermore, pre-service teachers should be made aware of their possible single-action bias (see Weber, 2010) by debunking their perceptions regarding the impact of different mitigative actions. One way to approach this would be to encourage the teachers to analyze their environmental actions critically (see Tolppanen, 2015), taking the carbon footprint of their actions into consideration. This process of critical analysis is what distinguishes environmental action from mere environmental behavior (see Jensen \& Schnack, 1997) and at best can lead to a dissatisfaction of current understanding and the openness to accommodate new beliefs (Posner et al., 1982) and ultimately new behavior (Bandura, 2011). One way to do this could be first to familiarize participants with the carbon emission cuts that need to be reached in the coming decades and then ask participants to create for themselves a "carbon diet," in which they reduce their personal carbon footprint by $10 \%, 20 \%$, or $30 \%$. In doing so, participants would need to examine the impact of each action on climate change, as well as their willingness to take those actions. Such a planning process could help participants realize the great difference in the impact of different mitigative actions, as well as help them to understand which actions by individuals are most needed in order to combat climate change. Ideally, it may even affect their willingness to take high-impact actions rather than only low-impact ones.

One reason why pre-service teachers do not distinguish between high-and low-impact actions could be that they may perceive climate change mitigation and environmental protection as one entity, assuming that everything that is good for the environment is also good for climate change mitigation, and vice-versa. In the current study, the strongest indication of mixing up environmental issues is seen in how pre-service teachers perceive nuclear power; although its mitigative impact is the same (or similar) as that of green energy, participants tend to think that it has a smaller mitigative impact. This is in line with previous studies that have shown that individuals do not necessarily see nuclear power as part of the solution to climate change mitigation (Vainio et al., 2017). Therefore, to develop pre-service teachers' education, a distinction between climate actions and general environmentally friendly actions needs to be made. One way to do this could be to compare the environmental impact and climate impact of several pro-environmental actions such as locally produced organic food in a cold climate and internationally produced food that has been sprayed with pesticides. In this comparison, ethical issues such as work conditions can also be considered in order to show the array of things that may affect our consumption habits. Based on the comparison, differences between environmental impact, climate impact, and social impact could be discussed to help people understand why they should be distinguished from each other.

\section{The Depth of the Knowledge-Behavior Gap}

The findings of this study show that pre-service teachers are mostly willing to take low-impact mitigative actions, but reluctant to take high-impact ones. This is in line with a previous qualitative study which indicated that Finnish teachers mainly state that they take only low-impact actions (Hermans, 2016). The findings also show that the teachers are aware that the actions they are willing to undertake may not have the greatest mitigative impact, suggesting that some level of a knowledge-behavior gap (see Kollmuss and Agyeman, 2002) exists. However, to understand the depth of the knowledge-behavior gap in climate change mitigation, we must first be confident that 
the participants answering a question correctly have not merely made a lucky guess. In many of the questions of this study (9/19), the participants received lower scores than if they had merely guessed their answers. Furthermore, participants' confidence in their knowledge was very low (4 $12 \%$ were confident in their answers) so, in order to understand whether a knowledge-behavior gap exists in climate change mitigation, it would be necessary first to improve the participants' level of knowledge of mitigative issues. For more in-depth analysis, it would also be useful to examine actual behavior rather than just intent, or willingness to act. However, as a knowledge-behavior gap has been shown to exist in environmental contexts other than climate change (Kollmuss \& Agyeman, 2002), it is fair to assume that such a gap also exists in climate change-related issues. One way to potentially decrease such a gap is to address the potential negative impacts of climate change and help students understand that these negative impacts are not distant problems, as they will be increasingly realized in the next few decades. Combining this knowledge to behavior could be done through exercises, such as the "carbon diet" explained above, as such tasks can help change habits and make planned behavioral change, rather than living spontaneously. The rationale to do so is that studies have shown that individuals most concerned about climate change are also the most willing to take action to mitigate it (SITRA, 2019). That said, if students see climate change mitigation as impossible, this can affect their emotional well-being (Pihkala, 2018), so students must be given abundant tools to mitigate climate change as individuals and members of society. These can include personal responsible action such as lifestyle choices, participatory actions such as voting, and future-oriented actions such as deciding to address climate change issues with their own students (see Vesterinen et al., 2016).

Interestingly, confidence in knowledge was found to have a stronger correlation with willingness to act than knowledge itself. This suggests that people want to be sure that they are making a significant environmental impact before undertaking mitigative actions that will affect their lives. It is also worth noting that confidence in knowledge correlated with some of the high-impact actions, but none of the low-impact actions. This may suggest that once an individual's confidence in the impact of certain actions increases, they are more willing to take those high-impact actions as they understand their significance. As confidence in knowledge has not been examined in previous studies, the low confidence found in this study also raises the uncomfortable question of how well previous studies have managed to measure knowledge rather than the hunches or lucky guesses of participants. We can assume that, at least in some of these studies where confidence has not been measured, it would be more correct to talk about a knowledge deficit rather than a knowledgebehavior gap. As confidence in knowledge seems to be a better indication of willingness to act than knowledge itself, future studies examining the relationship between climate change knowledge and willingness to act should take confidence in knowledge into consideration. Furthermore, to address the depth of the knowledge-behavior gap, future studies should examine whether increasing one's confidence in knowledge has an effect on willingness to act. Examining this more deeply may further help explain why individuals are not doing more to combat climate change, even though they show deep concern about it (ilmastobarometri, 2019). Based on our findings it seems that pre-service teachers do not know what they should do, or at least they do not believe that the impact of highimpact actions is as impactful as it truly is. Unfortunately, this indicates that the teachers do not have the tools to teach action competence (Jensen 2002; Jensen, \& Schnack, 1997) to their students, nor would they be able to answer their students' questions on climate change mitigation (see Tolppanen \& Aksela, 2018). Future studies should examine how pre-service teachers' knowledge of climate change mitigation can be improved, and how an improved level of knowledge and confidence may affect willingness to act, conceptual change, and actual behavior. One interesting area of focus in pre-service teacher education (at least in Finland) should be on the impact of walking 
short distances and changing the destination of long-distance flights. If participants could be encouraged to take these two actions alone, their annual carbon footprint would decrease by around 5-20\% a year. In both these categories, participants showed a relatively high willingness to act, although their level of knowledge was low. Furthermore, willingness to act increased as confidence in knowledge increased, so further studies should examine whether increasing knowledge of these two issues in particular could help pre-service teachers adopt a more environmentally friendly lifestyle. However, as previous studies indicate that a knowledgebehavior gap does exist in environmental issues (Kollmuss \& Agyeman, 2002), climate change education should not only focus on increasing knowledge, but also on providing a platform to discuss and evaluate values, social norms, and emotions, and to develop pre-service teachers' future-oriented thinking skills, as has been presented in the model for holistic climate change education (Tolppanen, et al., 2017; Cantell, et al., 2019). Studies have also found that presenting students with interesting and convincing reading on climate change may help them change their attitudes and willingness to act towards climate change mitigation (Sinatra et al. 2012).

\section{Limitations of the Study}

One of the limitations of this study is that it was conducted in a single country, Finland. Future studies should examine whether similar findings are found in other parts of the world, but as previous studies show that teachers have a low level of knowledge of climate change (see, e.g., Boon, 2010; Puk \& Stibbards, 2012; Lambert \& Bleicher, 2013), it is likely that their level of knowledge of mitigative issues is also low, as was found in this study. Another limitation is that this study did not examine how teaching practices affect pre-service teachers' knowledge and willingness to act on climate change, so the findings only shed light on the existence of a problem in education on climate change mitigation, but are not able to give concrete suggestions on how this problem could be solved, other than of course by stating that pre-service teachers' knowledge of mitigative actions needs to be increased. That said, future studies should examine pre-post test results after implementing an intervention on climate change issues, which also address mitigation.

\section{Conclusions}

In order to combat climate change through education, pre-service teachers' knowledge of climate change mitigation needs to be increased. As confidence in knowledge increases, individuals may also be more willing to take more high-impact mitigative actions. Most importantly, teachers will be able to educate the future generations on the lifestyle choices needed to significantly reduce carbon emissions. Increasing knowledge is one important aspect of climate change education, as it helps increase action competence among teachers and students. However, as this study and numerous previous studies show, the relationship between knowledge and willingness to take action is not straightforward and it is naïve to say that increasing knowledge of mitigative issues is sufficient to decrease carbon footprints significantly. Many other factors are also at play, and more research is needed to understand how pre-service teacher training can take these factors into consideration, so that our teachers will be able to train a new generation of critical and action-competent citizens.

Funding Information Open access funding provided by University of Eastern Finland (UEF) including Kuopio University Hospital. 


\section{Appendix}

Table 6

\begin{tabular}{|c|c|c|c|}
\hline Action & GHG impact data & Other assumptions & References \\
\hline $\begin{array}{l}\text { Traveling short distances on } \\
\text { foot or by bike } \\
(=100 \mathrm{~km} / \text { week })\end{array}$ & $\begin{array}{l}\text { Direct emissions from } \\
\text { petrol car } 135 \mathrm{~g} \\
\mathrm{CO}_{2} \mathrm{eq} / \mathrm{km} \\
\text { Emissions from petrol } \\
\text { car manufacturing } 20 \\
\mathrm{gCO}_{2} \mathrm{eq} / \mathrm{km} \\
\text { Petrol production } 15 \\
\mathrm{gCO}_{2} \text { eq/MJ }\end{array}$ & $\begin{array}{l}\text { Fuel consumption of petrol car } \\
2.3 \mathrm{MJ} / \mathrm{km}\end{array}$ & $\begin{array}{l}\text { Liikennevirasto } \\
2018 \\
\text { VTT Technical } \\
\text { Research } \\
\text { Centre of } \\
\text { Finland } 2017 \\
\text { Chester \& } \\
\text { Horvath } 2009\end{array}$ \\
\hline $\begin{array}{l}\text { Flying a mid-distance flight } \\
\text { (Barcelona) instead of a } \\
\text { long distance (Bangkok) }\end{array}$ & $\begin{array}{l}\text { Direct emissions of a } \\
\text { long-haul flight } 114 \\
\mathrm{gCO}_{2} \mathrm{eq} / \mathrm{pkm} \text { (passen- } \\
\text { ger km) } \\
\text { Direct emissions of a } \\
\text { long-distance flight } \\
165 \mathrm{gCO} 2 \mathrm{eq} / \mathrm{pkm} \\
\text { Emissions from plane } \\
\text { manufacturing } 7 \\
\mathrm{gCO}_{2} \mathrm{eq} / \mathrm{pkm} \\
\text { Emissions from jet fuel } \\
\text { manufacturing } 15_{\mathrm{gCO}_{2} \mathrm{eq} / \mathrm{MJ}}\end{array}$ & $\begin{array}{l}\text { Fuel consumption of a long-haul } \\
\text { flight } 1.6 \mathrm{MJ} / \mathrm{pkm} \\
\text { Fuel consumption of a } \\
\text { long-distance flight } 2.2 \mathrm{MJ} /- \\
\text { pkm } \\
\text { Length of long-haul flight } \\
16,000 \mathrm{~km} \\
\text { Length of long-distance flight } \\
5300 \mathrm{~km}\end{array}$ & $\begin{array}{l}\text { VTT Technical } \\
\text { Research } \\
\text { Centre of } \\
\text { Finland } 2009 \\
\text { Chester \& } \\
\text { Horvath } 2009\end{array}$ \\
\hline $\begin{array}{l}\text { Traveling by train across } \\
\text { Finland } \\
\text { (Helsinki-Rovaniemi) in- } \\
\text { stead of a mid-distance } \\
\text { flight (Barcelona) }\end{array}$ & $\begin{array}{l}\text { Emissions from train } \\
\text { manufacturing } 20 \\
\mathrm{gCO}_{2} \mathrm{eq} / \mathrm{pkm}\end{array}$ & $\begin{array}{l}\text { Electricity used is } 100 \% \text { hydro } \\
\text { energy } \\
\text { Length of train travel } 1800 \mathrm{~km}\end{array}$ & $\begin{array}{l}\text { VR Group } 2018 \\
\text { Chester \& } \\
\text { Horvath } 2009\end{array}$ \\
\hline $\begin{array}{l}\text { Changing petrol car for a } \\
\text { hybrid car }\end{array}$ & $\begin{array}{l}\text { Direct emissions from } \\
\text { petrol car } 135 \\
\mathrm{gCO}_{2} \mathrm{eq} / \mathrm{km} \\
\text { Emissions from petrol } \\
\text { car manufacturing } 20 \\
\mathrm{gCO}_{2} \mathrm{eq} / \mathrm{km} \\
\text { Petrol production } 15 \\
\mathrm{gCO}_{2} \text { eq/MJ } \\
\text { Emissions from electric } \\
\text { car manufacturing } 35 \\
\mathrm{gCO}_{2} \mathrm{eq} / \mathrm{km} \\
\text { Electricity production } \\
48.6 \mathrm{gCO}_{2} \mathrm{eq} / \mathrm{MJ}\end{array}$ & $\begin{array}{l}\text { Annual kilometers } 12,000 \mathrm{~km} \\
\text { Fuel consumption of petrol car } \\
2.3 \mathrm{MJ} / \mathrm{km} \\
\text { Electricity share for hybrids } \\
\quad 0.425\end{array}$ & $\begin{array}{l}\text { Liikennevirasto } \\
2018 \\
\text { VTT Technical } \\
\text { Research } \\
\text { Centre of } \\
\text { Finland } 2017 \\
\text { Plötz et al. } 2017 \\
\text { Chester \& } \\
\text { Horvath } 2009\end{array}$ \\
\hline $\begin{array}{l}\text { Changing petrol car for an } \\
\text { electric car }\end{array}$ & $\begin{array}{l}\text { Direct emissions from } \\
\text { petrol car } 135 \\
\mathrm{gCO}_{2} \mathrm{eq} / \mathrm{km} \\
\text { Emissions from petrol } \\
\text { car manufacturing } 20 \\
\mathrm{gCO}_{2} \mathrm{eq} / \mathrm{km} \\
\text { Petrol production } 15 \mathrm{~g} \\
\mathrm{CO}_{2} \text { eq/MJ } \\
\text { Emissions from electric } \\
\text { car manufacturing } 35 \\
\mathrm{gCO}_{2} \mathrm{eq} / \mathrm{km}\end{array}$ & $\begin{array}{l}\text { Annual kilometers } 12,000 \mathrm{~km} \\
\text { Electricity share for hybrids } \\
0.425 \\
\text { Fuel consumption of a petrol car } \\
2.3 \mathrm{MJ} / \mathrm{km} \\
\text { Electricity consumption of an } \\
\text { electric car } 0.7 \mathrm{MJ} / \mathrm{km}\end{array}$ & $\begin{array}{l}\text { Liikennevirasto } \\
2018 \\
\text { VTT Technical } \\
\text { Research } \\
\text { Centre of } \\
\text { Finland } 2017 \\
\text { Chester \& } \\
\text { Horvath } 2009\end{array}$ \\
\hline
\end{tabular}


(continued)

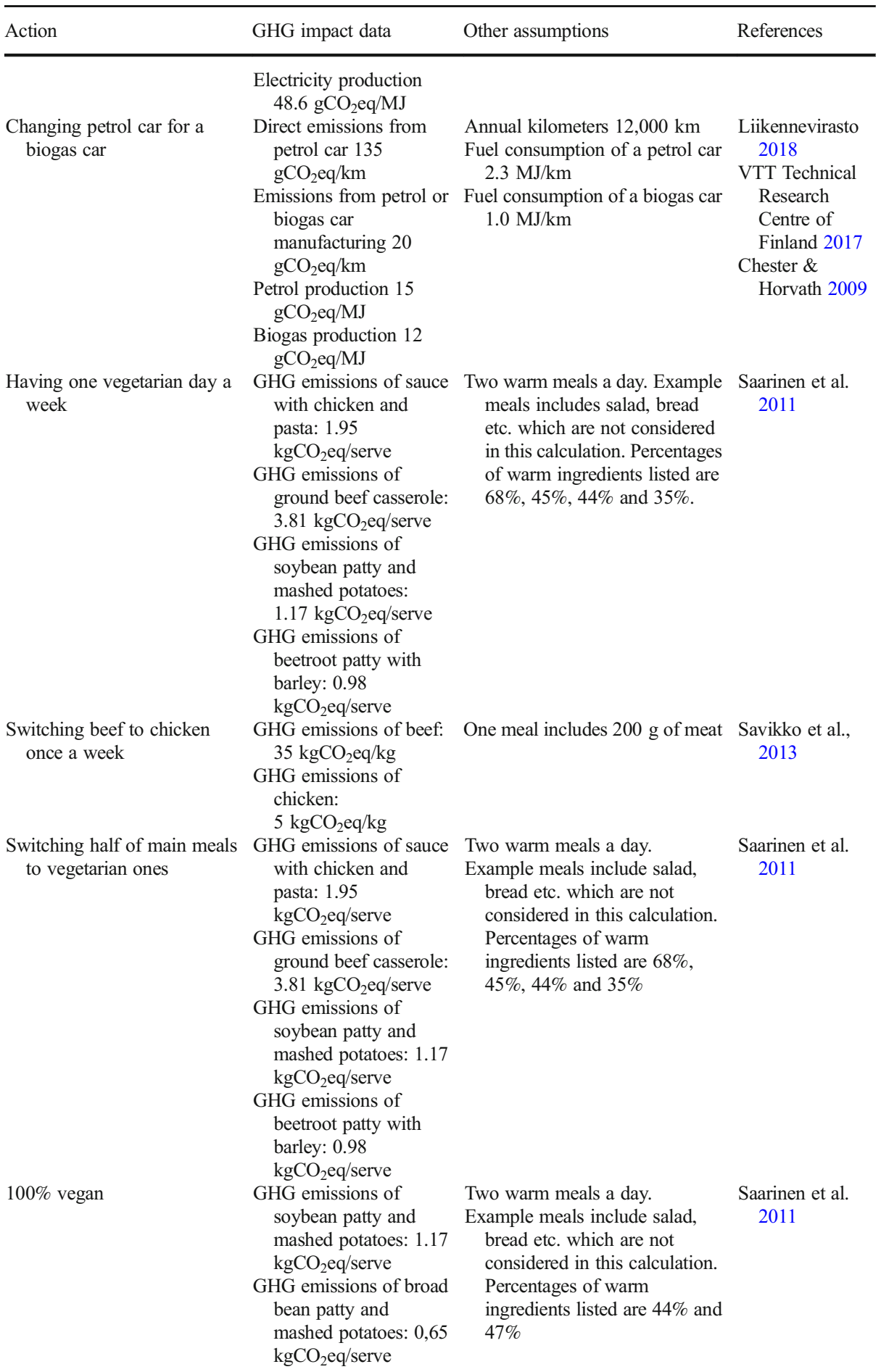


(continued)

\begin{tabular}{|c|c|c|c|}
\hline Action & GHG impact data & Other assumptions & References \\
\hline $\begin{array}{l}\text { Recycling of all paper, } \\
\text { cardboard, metal and glass }\end{array}$ & 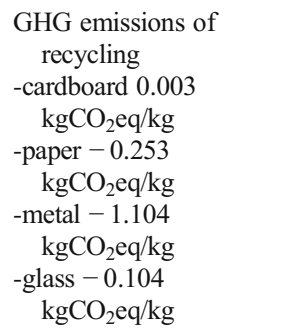 & $\begin{array}{l}\text { Amount of waste/person/a } \\
\text {-cardboard } 13 \mathrm{~kg} \\
\text {-paper } 15 \mathrm{~kg} \\
\text {-metal } 5 \mathrm{~kg} \\
\text {-glass } 4 \mathrm{~kg}\end{array}$ & $\begin{array}{l}\text { Saarinen } 2014 \\
\text { Lounais-Suomen } \\
\quad \text { jätehuolto } \\
2017 \\
\text { HSY } 2016\end{array}$ \\
\hline $\begin{array}{l}\text { Eating all leftovers and not } \\
\text { throwing any food away }\end{array}$ & $\begin{array}{l}\text { GHG emissions of a } \\
\text { person's food waste: } \\
190 \mathrm{kgCO}_{2} \mathrm{eg} / \mathrm{a}\end{array}$ & & $\begin{array}{l}\text { Häkkinen and } \\
\text { Kangas, } 2012\end{array}$ \\
\hline $\begin{array}{l}\text { Buying half of the clothes } \\
\text { second hand }\end{array}$ & $\begin{array}{l}\text { GHG emissions of an } \\
\text { average Swedish's } \\
\text { fashion purchases: } \\
250 \mathrm{kgCO}_{2} \text { eq/a }\end{array}$ & & Roos et al. 2015 \\
\hline $\begin{array}{l}\text { Using mobile phone } 2 \text { years } \\
\text { instead of a year before } \\
\text { getting a new one }\end{array}$ & $\begin{array}{l}\text { GHG emissions from } \\
\text { production and raw } \\
\text { materials of a } \\
\text { smartphone: } 49.8 \\
\mathrm{kgCO}_{2} \mathrm{eq}\end{array}$ & & Ercan et al. 2016 \\
\hline $\begin{array}{l}\text { Turning off all appliances } \\
\text { when not in use }\end{array}$ & $\begin{array}{l}\text { One person can save } \\
\text { approximately } 10.3 \\
\mathrm{kgCO}_{2} \mathrm{eq}\end{array}$ & & Sitra 2017 \\
\hline $\begin{array}{l}\text { Spending } 30 \text { min less in a } \\
\text { shower weekly }\end{array}$ & $\begin{array}{l}\text { GHG emissions of an } \\
\text { average Finnish } \\
\text { district heating: } 188 \\
\mathrm{gCO}_{2} \text { eq } / \mathrm{kWh}\end{array}$ & $\begin{array}{l}\text { Shower consumes water } 12 \mathrm{l} / \mathrm{min} \\
\text { Energy needed to heat } 11 \text { of } \\
\text { water: } 0.04 \mathrm{kWh} / 1\end{array}$ & $\begin{array}{l}\text { Motiva } 2018 \\
\text { Turku Energia } \\
\quad \text { (n.d.) }\end{array}$ \\
\hline $\begin{array}{l}\text { Switching to green/nuclear } \\
\text { electricity }\end{array}$ & $\begin{array}{l}\text { GHG emissions of an } \\
\text { average Finnish } \\
\text { electricity production: } \\
164 \mathrm{gCO}_{2} \text { eq } / \mathrm{kWh} \\
\text { GHG emissions of } \\
\text { green } / \text { nuclear energy: } \\
0 \mathrm{gCO}_{2} \text { eq } / \mathrm{kWh}\end{array}$ & $\begin{array}{l}\text { Energy consumption of } 2 \text { persons } \\
\text { living in an apartment: } 1900 \\
\mathrm{kWh} / \mathrm{a} \\
\text { Only direct emissions from } \\
\text { production phase are } \\
\text { considered. }\end{array}$ & $\begin{array}{l}\text { Motiva } 2018 \\
\text { Adato Energia } \\
\quad 2013\end{array}$ \\
\hline $\begin{array}{l}\text { Moving to a smaller } \\
\text { apartment }\end{array}$ & $\begin{array}{l}\text { GHG emissions of an } \\
\text { average Finnish } \\
\text { district heating: } 188 \\
\text { gCO }_{2} \text { eq } / \mathrm{kWh}\end{array}$ & $\begin{array}{l}\text { An average heating energy } \\
\text { consumption of } 1980 \text { 's } \\
\text { apartment building: } 55 \\
\mathrm{kWh} / \mathrm{m}^{3} / \mathrm{a}\end{array}$ & $\begin{array}{l}\text { Motiva } 2018 \\
\text { Motiva } 2016\end{array}$ \\
\hline $\begin{array}{l}\text { Replacing old windows with } \\
\text { new ones }\end{array}$ & $\begin{array}{l}\text { GHG emissions of an } \\
\text { average Finnish } \\
\text { district heating: } 188 \\
\mathrm{gCO}_{2} \mathrm{eq} / \mathrm{kWh} \\
\text { GHG emissions of an } \\
\text { average Finnish } \\
\text { electricity production: } \\
164 \mathrm{gCO}_{2} \mathrm{eq} / \mathrm{kWh}\end{array}$ & $\begin{array}{l}\text { New windows are } 200 \mathrm{kWh} / \mathrm{m}^{2} / \mathrm{a} \\
\text { more energy efficient than old } \\
\text { ones } \\
\text { Area of windows } 12 \mathrm{~m}^{2} \\
\text { Energy consumption of } \\
\text { producing timber-aluminum } \\
\text { framed window }(1.2 \times 1.2 \mathrm{~m}) \\
\text { with argon: } 4287 \mathrm{MJ} \\
\text { Finnish electricity mix used for } \\
\text { production } \\
\text { Lifespan of windows: } 50 \mathrm{a}\end{array}$ & $\begin{array}{l}\text { Motiva } 2016 \\
\text { Lumme Energia } \\
\quad 2014 \\
\text { Teenou } 2012\end{array}$ \\
\hline $\begin{array}{l}\text { Talking a friend living in an } \\
\text { average detached house } \\
\text { into switching to green } \\
\text { electricity }\end{array}$ & $\begin{array}{l}\text { GHG emissions of an } \\
\text { average Finnish } \\
\text { electricity production: } \\
164 \mathrm{gCO}_{2} \mathrm{eq} / \mathrm{kWh}\end{array}$ & $\begin{array}{l}\text { Energy consumption of } 4 \text { persons } \\
\text { living in a detached house: } \\
7300 \mathrm{kWh} / \mathrm{a}\end{array}$ & $\begin{array}{l}\text { Motiva } 2018 \\
\text { Adato Energia } \\
\quad 2013\end{array}$ \\
\hline
\end{tabular}


Open Access This article is licensed under a Creative Commons Attribution 4.0 International License, which permits use, sharing, adaptation, distribution and reproduction in any medium or format, as long as you give appropriate credit to the original author(s) and the source, provide a link to the Creative Commons licence, and indicate if changes were made. The images or other third party material in this article are included in the article's Creative Commons licence, unless indicated otherwise in a credit line to the material. If material is not included in the article's Creative Commons licence and your intended use is not permitted by statutory regulation or exceeds the permitted use, you will need to obtain permission directly from the copyright holder. To view a copy of this licence, visit http://creativecommons.org/licenses/by/4.0/.

\section{References}

Ambusaidi, A., Boyes, E., Stanisstreet, M., \& Taylor, N. (2012). Omani pre-service science teachers' views about global warming: Beliefs about action and willingness to act. International Journal of Environment \& Science Education, 7(2), 233-251.

Anderson, A. (2012). Climate change education for mitigation and adaptation. Journal of Education for Sustainable Development, 6(2), 191-206.

Attari, S. Z., DeKay, M. L., Davidson, C. I., \& De Bruin, W. B. (2010). Public perceptions of energy consumption and savings. Proceedings of the National Academy of Sciences, 107(37), 16054-16059.

Balmford, A., Cole, L., Sandbrook, C., \& Fisher, B. (2017). The environmental footprints of conservationists, economists and medics compared. Biological Conservation, 214, 260-269.

Bandura, A. (2011). The social and policy impact of social cognitive theory. Social psychology and evaluation, $33-70$.

Boon, H. J. (2010). Climate change? Who knows? A comparison of secondary students and pre-service teachers. Australian Journal of Teacher Education, 35(1), 104-120.

Boyes, E., Skamp, K., \& Stanisstreet, M. (2009). Australian secondary students' views about global warming: Beliefs about actions, and willingness to act. Research in Science Education, 39(5), 661-680.

Cantell, H., Tolppanen, S., Aarnio-Linnanvuori, E., \& Lehtonen, A. (2019). Bicycle model on climate change education: Presenting and evaluating a model. Environmental Education Research, 25(5), 717-731.

Chawla, L. (2009). Growing up green: Becoming an agent of care for the natural world. The Journal of Developmental Processes, 4(1), 6-23.

Chester, M. V., \& Horvath, A. (2009). Environmental assessment of passenger transportation should include infrastructure and supply chains. Environmental Research Letters, 4, 024008.

Dawson, V. (2015). Western Australian high school students' understandings about the socioscientific issue of climate change. International Journal of Science Education, 37(7), 1024-1043.

Emanuel, R., \& Adams, J. N. (2011). College students' perceptions of campus sustainability. International Journal of Sustainability in Higher Education, 12(1), 79-92.

Adato Energia. (2013). Kotitalouksien sähkönkäyttö 2011 [Household electricity consumption in 2011$].$ Retrieved on 3.2.2020 from: https://www.vattenfall.fi/globalassets/energianeuvonta/kodinsahkonkulutus/kotitalouksien_sahkonkaytto_2011_tutkimusraportti.pdf.

Lumme Energia. (2014). Riittääkö ikkunoiden tiivistäminen, vai pitääkö ikkunat vaihtaa? [Is it enough to insulate windows, or do they need to be changed?] Retrieved on 30.11.2019 from: https://energiaa.lumme-energia. fi/tiivistaa-vai-vaihtaa/

Turku Energia. (n.d.) Kodin ja veden lämmityksen sekä ilmanvaihdon vaikutukset energiankulutukseen. Available online: https://www.turkuenergia.fi/energiatietoa/energiansaastovinkit/energiansaastovinkit/kodinja-veden-lammitys/.

Ercan, M., Malmodin, J., Bergmark, P., Kimfalk, E., Nilsson, E. (2016) Life cycle assessment of a smartphone. 4th International Conference on IT for Sustainability.

Gibson, T., Arvesen, A., \& Hertwich, E. G. (2017). Life cycle assessment demonstrates environmental cobenefits and trade-offs of low-carbon electricity supply options. Renewable and Sustainable Energy Reviews, $76,1283-1290$.

Girod, B., van Vuuren, D. P., \& Hertwich, E. G. (2014). Climate policy through changing consumption choices: Options and obstacles for reducing greenhouse gas emissions. Global Environmental Change, 25, 5-15.

Häkkinen, H., \& Kangas, H. (2012). Suomalaisen vaikuttavimmat ilmastoteot [Most impactful climate actions for Finns]. WWF Suomi. Retrieved on 3.2.2020 from: https://wwf.fi/mediabank/1882.pdf .

Hermans, M. (2016). Geography teachers and climate change: Emotions about consequences, coping strategies, and views on mitigation. International Journal of Environmental and Science Education, 11(4), 389-408. 
Hertwich, E., \& Peters, G. (2009). Carbon footprint of nations: A global, trade-linked analysis. Environmental Science \& Technology, 43(16), 6414-6420.

HSY. (2016). Pääkaupunkiseudun seka- ja biojätteen koostumus vuonna 2015.[The capital regions waste and biowaste composition in 2015]. Available online: https://www.hsy. fi/sites/Esitteet/EsitteetKatalogi/Raportit/Paakaupunkiseudun_seka-ja_biojatteen_koostumus_vuonna_2015. pdf

Ikonomidis, S., Papanastasiou, D., Melas, D., \& Avgoloupis, S. (2012). The anthropogenic 'greenhouse effect': Greek prospective primary teachers' ideas about causes, consequences and cures. Journal of Science Education and Technology, 21(6), 768-779.

Ilmastobarometri (2019). Ilmastobarometri 2019: Suomalaiset haluavat ilmastokriisin ratkaisut politiikan ytimeen [Climate barometer 2019: Finns want the climate crisis to be at the center of politics]. Ministry of Environment: Ilmastoviestinnän ohjausryhmä ja Kantar TNS. Retrieved from: https://www.ym.fi/fiFI/Ajankohtaista/Ilmastobarometri_2019_Suomalaiset_haluav(49670).

IPCC. (2014a). Climate change 2014: Impacts, adaptation, and vulnerability. Working group II contribution to the fifth assessment report of the Intergovernmental Panel on Climate Change. Cambridge: Cambridge University Press.

IPCC. (2014b). Climate change 2014: Mitigation of climate change. Contribution of working group III to the fifth assessment report of the Intergovernmental Panel on Climate Change. Cambridge: Cambridge University Press.

Ivanova, D., Stadler, K., Steen-Olsen, K., Wood, R., Vita, G., Tukker, A., \& Hertwich, E. G. (2015). Environmental impact assessment of household consumption. Journal of Industrial Ecology, 20(3), 526-536.

Lounais-Suomen jätehuolto. (2017). Vuosikatsaus 2016. [Anual report 2016]Available online: https://lsjh.ejulkaisu.fi/vuosikatsaus2016/

Jensen, B. B. (2002). Knowledge, action and pro-environmental behaviour. Environmental Education Research, $8(3), 325-334$.

Jensen, B. B., \& Schnack, K. (1997). The action competence approach in environmental education. Environmental Education Research, 3(2), 163-178.

Jones, C., \& Kammen, D. (2011). Quantifying carbon footprint reduction opportunities for U.S. Households and Communities Environmental Science \& Technology, 45(9), 4088-4095.

Kollmuss, A., \& Agyeman, J. (2002). Mind the gap: Why do people act environmentally and what are the barriers to pro-environmental behavior? Environmental Education Research, 8(3), 239-260.

Lambert, J. L., \& Bleicher, R. E. (2013). Climate change in the pre-service teacher's mind. Journal of Science Teacher Education, 24(6), 999-1022.

Liikennevirasto. (2018). Henkilöliikennetutkimus 2016 - Suomalaisten liikkuminen. [Study on travel behavior in Finland 2016]Available online: https://julkaisut.vayla.fi/pdf8/lti_2018-01_henkiloliikennetutkimus_2016_ web.pdf

Lim, T. H., De Kleine, R. D., \& Keoleian, G. A. (2016). Energy use and carbon reduction potentials from residential ground source heat pumps considering spatial and economic barriers. Energy and Buildings, 128, 287-304.

Lorenzoni, I., Nicholson-Cole, S., \& Whitmarsh, L. (2007). Barriers perceived to engaging with climate change among the UK public and their policy implications. Glob Environ Change, 17(3), 445-459.

Motiva. (2016). Lämmitysenergiankulutus. [Use of energy for heating]Available online: https:/www.motiva. fi/koti_ja_asuminen/taloyhtiot/energiaeksperttitoiminta/tietoa_energian-_ja vedenkulutuksesta/lammitysenergiankulutus

Motiva. (2018). CO2-päästökertoimet [CO2-emission multiples].Available online: https://www.motiva. fi/ratkaisut/energiankaytto_suomessa/co2-laskentaohje_energiankulutuksen_hiilidioksidipaastojen_ laskentaan/co2-paastokertoimet

Pihkala, P. (2018). Eco-anxiety, tragedy, and hope: Psychological and spiritual dimensions of climate change. Journal of Religion and Science, 53(2), 545-569.

Plötz, P., Funke, S. Á., \& Jochem, P. (2018). Empirical Fuel Consumption and CO2 Emissions of Plug-In Hybrid Electric Vehicles. Journal of Industrial Ecology, 22(4), 773-784.

Posner, G. J., Strike, K. A., Hewson, P. W., \& Gertzog, W. A. (1982). Accommodation of a scientific conception: Toward a theory of conceptual change. Science Education, 66(2), 211-227.

Puk, T. G., \& Stibbards, A. (2012). Systemic ecological illiteracy? Shedding light on meaning as an act of thought in higher learning. Environmental Education Research, 18(3), 353-373.

Ratinen. (2013). Primary student-teachers' conceptual understanding of the greenhouse effect: A mixed method study. International Journal of Science Education, 35(6), 929-955.

Roos, S., Sandin, G., Zamani, B., \& Peeters, G. (2015). Environmental assessment of Swedish fashion consumption. Five garments - sustainable future. Mistra Future Fashion.

Saarinen, E. 2014. Kierrätyksen ympäristöhyödyt on arvioitu. Uusiouutiset 6/2014. Available online: https://uusiouutiset.fi/UU614ilmasto.pdf. 
Saarinen, M., Kurppa, S., Nissinen, A., \& Mäkelä, J. (2011). Aterioiden ja asumisen valinnat kulutuksen ympäristövaikutusten ytimessä [Consumption choices in food and living at the core of environmental impact]. ConsEnv-hankkeen loppuraportti. Suomen ympäristö 14. Helsinki, Ympäristöministeriö. ISBN 978-952-11-3897-3 (pdf), ISSN 1796-170X (verkkoj.). 97 s.

Salo, M., \& Nissinen, A. (2017). Consumption choices to decrease personal carbon footprints of Finns. Reports of the Finnish Environmental Institute 30/2017. ISBN 978-952-11-4875-0.

Savikko, R., Himanen, S., Rimhanen, K., \& Mäkinen, H. (2013). Ruoan ilmastovaikutukset [Climate impact of food]. Ilmastoviisaita ratkaisuja maaseudulle/Vilma. Luonnonvarakeskus. Retrieved on 3.2.2020 from: https://www.ilmase.fi/tietopaketit/ruoan-ilmastovaikutukset/.

Schreiner, C., Henriksen, E., \& Hansen, P. (2005). Climate education: Empowering today's youth to meet tomorrow's challenges. Studies in Science Education, 41(1), 3-49.

Sinatra, G. M., Kardash, C. M., Taasoobshirazi, G., \& Lombardi, D. (2012). Promoting attitude change and expressed willingness to take action toward climate change in college students. Instructional Science, 40(1), 1-17.

Sitra. (2017). Helppoa säästöä jatkojohdolla [Easy saving using a extention cord]. Retrieved on 6.11.2019 from: https://www.sitra.fi/caset/helppoa-saastoa-jatkojohdolla/

SITRA. (2019). Kestävät elämäntavat auttavat ilmastoahdistukseen [A sustainable lifestyle helps deal with climate anxiety]. Retrieved on 6.11.2019 from: https:/www.sitra.fi/uutiset/kestavat-elamantavat-auttavatilmastoahdistukseen/

Steg, L., \& Vlek, C. (2009). Encouraging pro-environmental behaviour: An integrative review and research agenda. Journal of Environmental Psychology, 29(3), 309-317.

Teenou, R. Y. (2012). Energy and CO2 emissions associated with the production of multi- glazed windows. Master's Thesis: Mid Sweden University.

Tolppanen, S. (2015). Creating a better world: Questions, actions and expectations of international students on sustainable development and its education (doctoral thesis). Helsinki: University of Helsinki Retrieved from http://urn.fi/URN:ISBN:978-951-51-1312-2.

Tolppanen, S., \& Aksela, M. (2018). Identifying and addressing students' questions on climate change. The Journal of Environmental Education, 49(5), 375-389.

Tolppanen, S., Cantell, H., Aarnio-Linnanvuori, E., \& Lehtonen, A. (2017). Pirullisen ongelman äärellä kokonaisvaltaisen ilmastokasvatuksen malli [Dealing with a wicked problem - A model for holistic climate change education]. Kasvatus, 5, 456-468.

Vainio, A., Paloniemi, R., \& Varho, V. (2017). Weighing the risks of nuclear energy and climate change: Trust in different information sources, perceived risks, and willingness to pay for alternatives to nuclear power. Risk Analysis, 37(3), 557-569.

Vesterinen, V. M., Tolppanen, S., \& Aksela, M. (2016). Toward citizenship science education: What students do to make the world a better place? International Journal of Science Education, 38(1), 30-50.

VR Group. (2018). Vastuullisuusraportti 2017 [Responsibility report, 2017]. Retrieved on 6.11.2019 from: https://2017.vrgroupraportti.fi/fi/

VTT Technical Research Centre of Finland. (2009). LIPASTO -calculation system. Available online: http://lipasto.vtt.fi/yksikkopaastot/henkiloliikennee/ilmaliikennee/ilmae.htm

VTT Technical Research Centre of Finland. (2017). LIPASTO unit emission database. Available online: http://lipasto.vtt.fi/yksikkopaastot/henkiloliikennee/tieliikennee/henkiloautote/habense.htm

Weber, E. U. (2010). What shapes perceptions of climate change? Wiley Interdisciplinary Reviews: Climate Change, 1(3), 332-342.

Wynes, S., \& Nicholas, K. (2017). The climate mitigation gap: Education and government recommendations miss the most effective individual actions. Environmental Research Letters, 2017(12), 074024.

Zsóka, Á., Szerényi, Z. M., Széchy, A., \& Kocsis, T. (2013). Greening due to environmental education? Environmental knowledge, attitudes, consumer behavior and everyday pro-environmental activities of Hungarian high school and university students. Journal of Cleaner Production, 48, 126-138.

Publisher's Note Springer Nature remains neutral with regard to jurisdictional claims in published maps and institutional affiliations. 